\title{
Sustainable development of West African Power Pool: Increasing solar energy integration and regional electricity trade
}

Omotola Adeoye ${ }^{\mathrm{a}^{*}}$, Catalina Spataru ${ }^{\mathrm{a}}$.

${ }^{a}$ UCL Energy Institute, University College London, United Kingdom.

\begin{abstract}
The West African region is currently experiencing the challenge of meeting rapidly the growing electricity demand which has played a critical role in the low economic development rate of the region. To tackle these challenges, the West African Power Pool was established to build regional power plants and interconnected transmission infrastructures between the countries. In this study, we develop a multi-region economic dispatch model with hourly simulations to evaluate the impact of increased integration of solar PV on the interconnected West Africa electricity network. Our results show the high integration of solar PV plants reduces the supplydemand gap and load shedding in the region. All countries in the region potentially benefit from avoided generation cost and decrease in unserved electricity demand. Our study presents a sustainable strategy to diversify from hydro and gas regional projects and invest in solar PV in order to improve electricity supply and reduce the high electricity prices in the region.
\end{abstract}

\section{KEYWORDS}

West African Power Pool, interconnected electricity network, cross-border electricity trade, solar photovoltaic, power system modelling, economic dispatch.

Declarations of interest: none

\footnotetext{
* Corresponding author at Central House, 14 Upper Woburn Place, London, WC1H 0NN

Email address: omotola.adeoye.14@ucl.ac.uk
} 


\section{Introduction}

In 2016, with a population of 327 million people and a maximum available generating capacity of $12 \mathrm{GW}, 14^{1}$ out of 15 countries in the West Africa region had an estimated 25.6GW peak demand (WAPP- Information and Coordination Centre, 2016). This illustrates the current huge gap between electricity supply and demand in West Africa and is reflected in the frequent electricity outages and load shedding experienced in each country. These outages have resulted in increased usage of diesel or petrol backup generators in domestic and industry sectors. This challenge has played a critical role in the low economic development rate of the region, as countries have not been capable of providing electricity for industrial activities (Castellano, Kendall, Nikomarov, \& Swemmer, 2015). Furthermore, electricity demand in West African countries is estimated to reach two times its present level by 2030 with an average annual growth rate of 6\% (International Energy Agency, 2014a). There is an urgent need for sustainable strategies to meet the rapidly growing electricity demand in West Africa.

In an effort to tackle these challenges and improve the economies of West African countries, The Economic Community of West African States (ECOWAS) established the West African Power Pool (WAPP) to develop large regional power plants, build interconnected transmission infrastructures between the countries and create a unified regional electricity market (West African Power Pool, 1999). The WAPP business plans (West African Power Pool, 2015) aims to increase regional generation capacity by $2.4 \mathrm{GW}$ and interconnect these 14 countries with $6,109 \mathrm{~km}$ of high voltage transmission lines by 2025 . This current regional plan focuses on hydropower and natural gas projects, representing $74 \%$ and $23 \%$ respectively of the planned generation capacity. Hindrances to this plan are the impact of drought and climate change on hydropower plants, and vandalism on gas pipelines. In 1998, 2001, 2007 because of severe drought, Cote D'Ivoire, Ghana, and Nigeria that rely heavily on hydropower experienced significant reductions in electricity production, which in turn affected electricity trades between countries. Furthermore, climate change could potentially reduce hydropower generation by more than $50 \%$ from two main rivers in the region between 2015 to 2050 (Cervigni, Liden, Neumann, \& Strzepek, 2015). Vandalism on several gas pipelines in Nigeria since 2012 has resulted in significant drop in electricity generation in both Nigeria and Ghana. However, the region has the potential to generate up to five times its 2025 projected demand from solar Photovoltaic (PV), if $1 \%$ of the estimated suitable land is utilized (Hermann, Miketa, \& Fichaux, 2014). With a solar PV technical potential of $103 \mathrm{PWh}$ in the region and the challenges with hydropower and gas generation, there is a need to investigate the impact of high integration of solar energy resources in meeting the rapidly growing demand of an interconnected West Africa electricity network under the operation of a single regional electricity market.

In this study, we developed a multi-region economic dispatch model with hourly simulations to evaluate the impacts of increased integration of grid connected solar PV plants to the interconnected West Africa electricity network. By developing a highly spatial and temporal model, we are able to model the varying outputs from solar PV plants installed in different locations in the region. We investigate two scenarios with different levels of solar energy integration in the year 2025. In the baseline scenario, we model a realistic condition of the system by assuming all existing and planned generation and interconnection infrastructures are operational. The renewable scenario increases solar PV integration based on the solar PV technical potential in each country. To analyse the impact of increased solar PV in the system,

\footnotetext{
${ }^{1}$ West African countries include Benin, Burkina Faso, Cote D'Ivoire, Gambia, Ghana, Guinea, Guinea Bissau, Liberia, Mali, Niger, Nigeria, Senegal and Sierra Leone and Togo.
} 
we compare the economic dispatch of generation units, generations costs and cross-border electricity trades from the two scenarios. This study addresses the following research questions:

1. What is the impact of high integration of solar energy sources in closing the supply-demand gap in West Africa and meeting rapidly growing demand?

2. With high integration of solar PV plants, what are the potential benefits of cross-border electricity trading in the West Africa's interconnected electricity network?

The rest of the paper is structured as follows; Section 2 presents a review on related literature and highlights the contribution of this study. Section 3 describes the model, data inputs and scenarios developed. Section 4 presents the results from the two scenarios and sensitivity analysis on demand and fuel prices. Section 5 summarizes conclusions from the simulation results and presents an overview of future research.

\section{Related research studies}

There have been a number of studies that analyse the impact of integrating high amounts of renewable energy sources on the operation of generation and transmission infrastructures in interconnected electricity networks between different countries. The type of renewable energy resources examined in literature is dependent on its economic potential in the given region or countries. For example, Van Hulle et al. (2009) investigated the impact of increasing wind capacities on the flow of electricity between several countries in Europe and concluded that upgrades to interconnections between countries and national grids is required to avoid congestion in the network. The authors in (Jaehnert, Wolfgang, Farahmand, Voller, \& Huertas-Hernando, 2013) examined how large amounts electricity generated from Nordic hydro power plants can be utilized to balance the fluctuating supply from other variable renewable energy sources. Brancucci Martínez-Anido et al. (2013) showed that high integration of variable renewables sources in the European interconnected electricity network has the benefit of reducing dispatch costs from conventional power plants. Schmid \& Knopf (2015) concluded that in a decarbonized scenario, the expansion of the European electricity network has the potential of reducing the total system costs up to 3.5\% over a 40-year period. The authors in (Dominković et al., 2016) analysed a 100\% renewable energy scenario in South East Europe and concluded that by integrating the various sectors of the energy system and utilizing heat energy storage, there was significant savings of primary energy consumption in the region. During cross border electricity exchanges, due to the limits of transmission lines between countries there are sometimes unplanned electricity flows through other neighbouring countries that have sufficient capacities in their grids. Jacottet (2012) finds that because the economic costs of such flows can be challenging to quantify, there have been no reimbursement to transmission system operators that experience these intrusions in their grid.

Several energy and power system models have been developed in modelling the integration of renewable energy sources in interconnected electricity networks. Most of these models represent a country (Brancucci Martínez-Anido et al., 2013; Collins, Deane, \& Gallachóir, 2017; Spataru \& Barrett, 2012; Spiecker, Vogel, \& Weber, 2013; Zickfeld, Wieland, Blohmke, Sohm, \& Yousef, 2012) or group of countries (Brouwer, van den Broek, Zappa, Turkenburg, \& Faaij, 2016; Haller, Ludig, \& Bauer, 2012) as a node in the network, with generating capacities and interconnected transmission lines aggregated by fuel type and line limit capacities respectively. However, recent studies have started increasing the spatial resolution of their models by dividing countries into subregions in order to better represent the interconnected grid and intermittent characteristics of renewable energy sources in different locations. Fürsch et al. (2013) models the ENTSOE-E countries as 224 nodes to account for load flow in the region and calculates the interconnected grid extensions required in a low carbon Europe by 2050. In examining cost efficient extensions to the 
entire European electricity network in 2020 following high penetration of wind and solar, the authors in (Schaber, Steinke, \& Hamacher, 2012) used the URBS-EU model and split the network into 83 regions; 50 transmission network operators and 33 offshore areas. Least cost pathways for a sustainable ASEAN electricity system are presented in (Huber, Roger, \& Hamacher, 2015), and a URBS-ASEAN model is used in the study to divide 11 countries in South-East Asia into 33 regions based on load centres and location of energy resources. Bogdanov \& Breyer (2016) divide 5 countries in North-East Asia into 13 regions based on national boundaries and transmission grid division in China, with the aim of analysing a fully renewable and cost-effective grid in the region. While 4 countries in North-Asia are divided into 10 regions in (Otsuki, Mohd Isa, \& Samuelson, 2016) based on supply facilities and electricity demand locations in order to determine the benefits and barriers of increasing renewables energy production and interconnections in the region. The model in (Eser, Singh, Chokani, \& Abhari, 2016) is an exception as it does not divide the interconnected countries in Central and Western Europe, but instead models all generating power plants and high voltage transmission lines in the region. However, the model in (Eser et al., 2016) only focuses on the impact of renewables plants on thermal power plants.

There are a few studies on modelling the interconnected electricity network in West Africa. Initial studies addressed the need for an interconnected electricity network in West Africa. The following reports (United Nations Economic Commission for Africa, 2003; World Energy Council, 2003, 2005) present the interconnection of national grids as a solution to the challenges of low access and unreliable supply of electricity in the region. An interconnection strategy was presented in (Gnansounou, 2008; Gnansounou, Bayem, Bednyagin, \& Dong, 2007), where there would be more than just electricity exchange among countries but also a single electricity market for the entire region. This strategy showed a potential cost savings of $38 \%$ over a period of 20 years (Gnansounou et al., 2007). Sparrow, Masters, \& Bowen (2002) developed a cost optimization model that indicated up to a $20 \%$ savings in total operation cost can be achieved from interconnections in West Africa over a 10-year period. The SPLAT model developed in (Miketa \& Merven, 2013) quantifies the investment costs needed to have a regional electricity mix constituting 56\% renewable energy sources by 2030 as $\$ 55$ billion. These aforementioned models for West Africa represent each country as a node and thus do not consider the spatial intermittency of renewable energy sources in the region.

So far to our knowledge, there is a lack of highly spatial power system model for West Africa region that considers the impact of high integration of solar energy in meeting the rapidly growing demand in the region under the operation of a single regional electricity market. Our study contributes first to literature on increasing the spatial resolution of interconnected electricity network models, and adequately representing the intermittent characteristics of solar energy resources in different locations. Secondly, our study contributes to understanding the role and benefits of grid connected solar PV plants in the WAPP.

\section{Methodology}

\subsection{The West African interconnected power system model}

PLEXOS Integrated Energy Modelling tool (PLEXOS, 2016) developed by Energy Exemplar is used in this study to model the West African interconnected power system. PLEXOS is used to solve the economic dispatch problem in the region with an objective function that minimizes the total generation cost which includes fuel costs, Operating and Maintenance (O\&M) costs and startup costs as shown in Equation 1. Optimization of generation plants dispatch levels is subject to three system constraints (Equations 2-4). 
Min $\sum_{y}\left(\right.$ FO\&MCost $_{g}$ X Pmaxg $)+\sum_{t}\left(\right.$ GenLoad $_{g, t} X\left(\left(\right.\right.$ FuelPrice $_{g}$ X HeatRate $)+$

VO\&MCost $g))+\sum_{t}\left(\right.$ GenOn $_{g, t} X$ StartCostg $)$

$\sum_{t}($ GenLoad + Unserved $)=$ Demand $_{t}$

Pming $\leq$ GenLoadg $\leq$ Pmaxg

GenCap $=$ Pmaxg-Outage

FO\&MCost $t_{g}=$ Fixed operating and maintenance cost of generation unit $\mathrm{g}(\$ / \mathrm{kW} /$ Year $)$

$\operatorname{Pmax}_{g}$ Pmin $_{g}$, $=$ Maximum and Minimum generating levels of each generation unit $\mathrm{g}$ (MW)

GenLoad $_{g, t}=$ Dispatch level of generating unit $\mathrm{g}$ in period ${ }_{\mathrm{t}}(\mathrm{MW})$

FuelPrice $_{g}=$ Fuel cost of generator ${ }_{g}(\$ / G J)$

HeatRate $_{g}=$ Heat rate of generator $\mathrm{g}(\mathrm{GJ} / \mathrm{MWh})$

$V O \& M C_{\text {ost }}=$ Variable operations and maintenance cost of generation unit $\mathrm{g}(\$ / \mathrm{MWh})$

$\mathrm{GenOn}_{g, t}=$ Generation unit switched on in period $\mathrm{t}_{\mathrm{t}}$

StartCost $t_{g}=$ Cost for starting up generation unit after an outage $(\$ / \mathrm{MW})$

Unserved $=$ Unserved demand in dispatch period $\mathrm{t}(\mathrm{MW})$

GenCap $=$ Available generation capacity (MW)

OutageRate $=$ Unavailable capacity due to outage event (MW)

The optimization process used in this study is in three phases as shown in Figure 1. The projected assessment of system adequacy phase determines when outages will occur in the power system while considering the peak demand periods, generation and transmission capacities. The medium term schedule phase optimizes the long term constraints of seasonal and annual energy dispatch levels of run-of -river hydro power plants. The short term dispatch phase optimizes the unit commitment and dispatch of generation plants in an hourly interval for the entire year. PLEXOS uses $\mathrm{AMMO}^{2}$ to formulate the mixed integer optimization equations which are solved using EELPS solver.

The West African model developed in this study represents 14 of the 15 member countries of ECOWAS and they include; Benin, Côte d'Ivoire, Burkina Faso, Ghana, Gambia, Guinea, Guinea Bissau, Liberia, Mali, Niger, Nigeria, Senegal, Sierra Leone, Togo. To account for the demand variation and intermittency (spatial and temporal) of solar energy in each country, the model has a spatial resolution of 33 regions and temporal resolution of 1 hour in the year 2025 . The 33 regions as shown in Figure 2, represent the interconnection nodes in each country and have 25 transmission interconnectors between them. The time horizon of the year 2025 is chosen for this study as all the proposed WAPP projects (West African Power Pool, 2015) are expected to be completed by 2023 .

\footnotetext{
${ }^{2}$ AMMO is a mathematical language written exclusively for PLEXOS.
} 


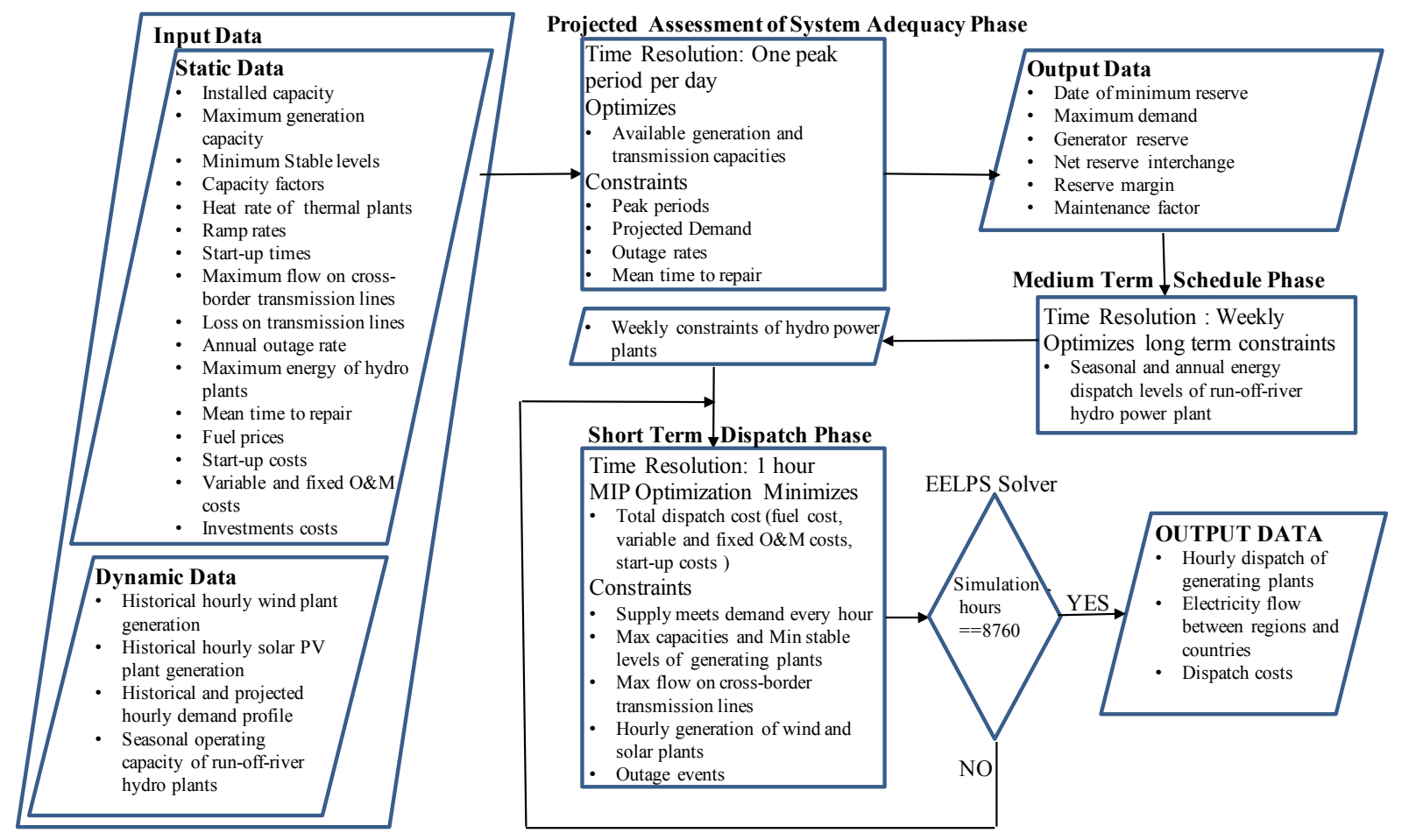

Figure 1. Flow Chart of West African PLEXOS model.

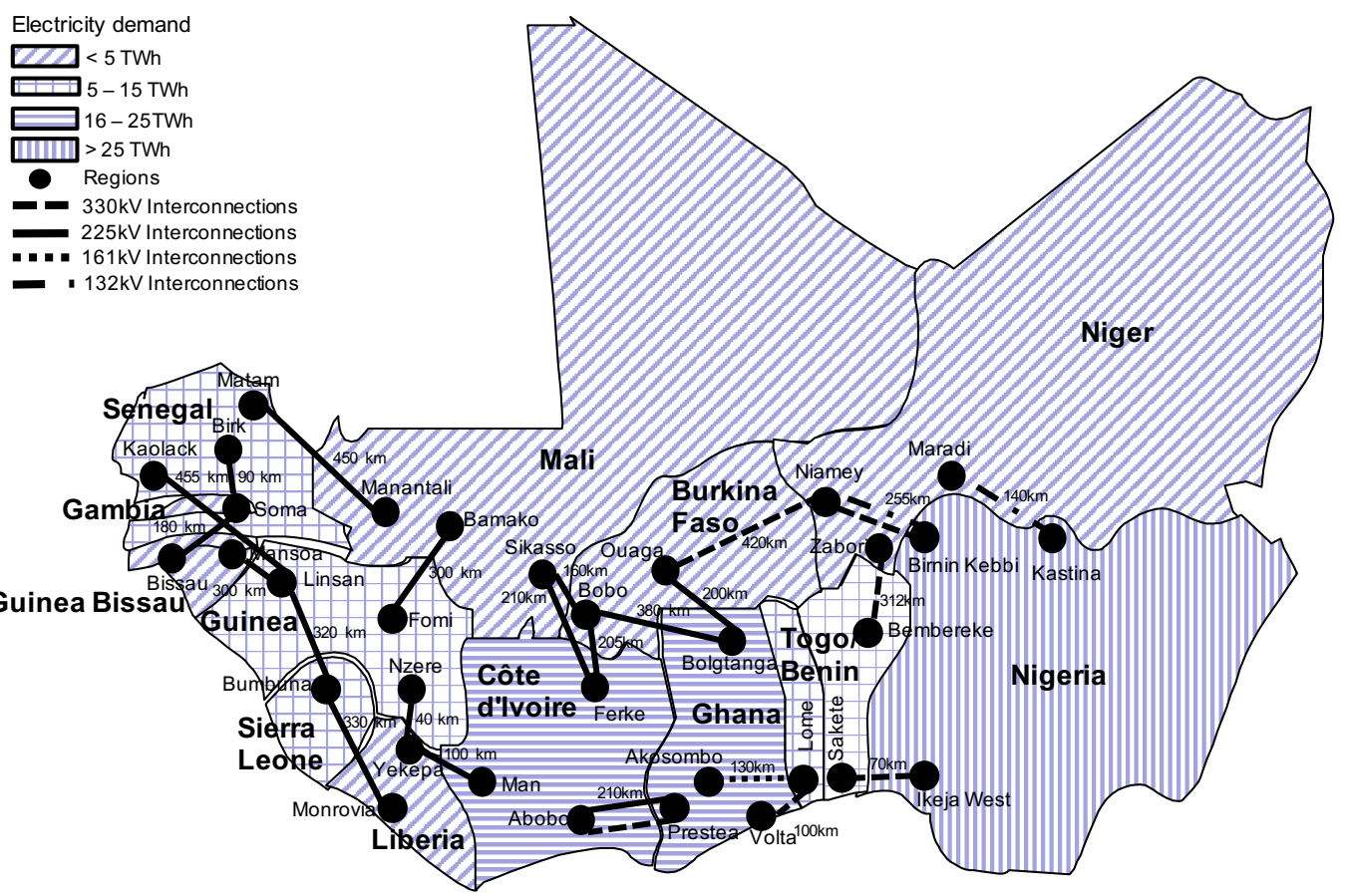

Figure 2. Existing and Proposed Interconnections in West Africa by 2025. 


\subsection{Data}

The hourly demand profiles for each country in 2009 were obtained from the IRENA study (Miketa \& Merven, 2013). The demand profiles for 2025 were built in PLEXOS from the 2009 profiles and the projected 2025 energy consumption and maximum demand data obtained from the WAPP master plan study data (West African Power Pool, 2011). The generated 2025 demand profile for each country were subsequently divided to each region in the country based on weighted urban and rural population (World Bank, 2015). The limitation of this method is the population levels are based on 2015 data which could change significantly and result in a shift of regional demand distribution in each country. The projected regional peak demand in 2025 is $32.6 \mathrm{GW}$ with an energy consumption of $204 \mathrm{TWh}$, the detailed data for each country is presented in Table 1 in the Appendix.

In addition to the existing generation power plants in each country, national and regional planned plants are included in the 2025 interconnected electricity network. In the model, generation units are aggregated by fuel types based on their proximity to the regions in each country. Thermal generation units include gas, diesel and coal and are modelled by defining their installed capacity, maximum capacity, minimum stable levels and heat rate. Table 1 contains the technical parameters of the different types of generation units while data for installed capacities were taken from (ECOWAS Observatory for Renewable Energy and Energy Efficiency, 2016). Power plant outage levels are based on scheduled maintenance and power failure conditions in the region. The hydro power plants in the region include run-off-river and dam plants and are modelled by their annual energy production (West African Power Pool, 2011). We assume all hydro plant units operate at a minimum operating dispatch level of $15 \%$ in dry seasons (November to April) and $40 \%$ in wet season (May - October).

\begin{tabular}{|l|l|l|l|l|l|l|l|}
\hline Technical Parameter & Gas & Diesel & Coal & Hydro & Solar PV & Wind & Biomass \\
\hline Minimum Stable level (\%) & 25 & 30 & 30 & $15-40 \%$ & - & - & 25 \\
\hline Capacity Factor (\%) & 85 & 80 & 85 & - & 20 & 25 & 60 \\
\hline Heat Rate (GJ/MWh) & 7.6 & 10.7 & 10.5 & - & - & - & 7.6 \\
\hline $\begin{array}{l}\text { Ramp Rate (\% max } \\
\text { capacity/min) }\end{array}$ & 20 & 8 & 4 & 5 & - & - & 8 \\
\hline Start-up time (hours) & 0.16 & 3 & 4 & 0.16 & - & - & 3 \\
\hline Outage Rate (\%) & 15 & 17 & 15 & 6 & 2 & 5 & 15 \\
\hline Mean Time to repair (hrs) & 50 & 50 & 50 & 50 & 50 & 50 & 50 \\
\hline
\end{tabular}

Table 1. Technical parameters for each type of generation plant (Brouwer, van den Broek, Seebregts, \& Faaij, 2015; International Energy Agency, 2014b, 2016b, 2017; West African Power Pool, 2011)

There are currently no national or regional plans for concentrated solar power plants, so we have only considered solar PV power plants in this study. The hourly solar PV profiles for the different regions in the year 2014 were obtained from (Pfenninger \& Staffell, 2016b) which is based on the methodology in (Pfenninger \& Staffell, 2016a). The hourly solar PV profiles were calculated based on the MERRA-2 weather dataset, which has a spatial resolution of $0.5^{\circ} \times 0.625^{\circ}$. The data for the solar PV optimum monthly average tilt and azimuth angles parameters were from (National Aeronautics and Space Administration, 2016) based on a 22-year period from 1983 - 2005. Similarly, the wind profiles in 2014 were calculated from (Pfenninger \& Staffell, 2016b) based on the Vesta V80 model with hub height of 80meters. Table 2 shows the economic parameters for the 
generation power plants with the monetary value assumed to be 2015 US\$. The projected 2025 fuel prices were obtained from IEA World Energy Outlook 2016 new policy scenario (International Energy Agency, 2016b) which accounts for existing and recently published policies affecting the energy market. Warm start-up costs (Brouwer et al., 2015) are based on 12-72 hours shut down period for the power plants.

\begin{tabular}{|l|l|l|l|l|l|l|l|}
\hline Economic Parameter & Gas & Diesel & Coal & Hydro & $\begin{array}{l}\text { Solar } \\
\text { PV }\end{array}$ & Wind & Biomass \\
\hline Domestic Fuel Price (\$/GJ) & 3.85 & - & 1.87 & - & - & - & 3.6 \\
\hline Imported Fuel Price $(\$ / G J)$ & 9.12 & 13.43 & - & - & - & - & - \\
\hline VO\&M Cost $(\$ / M W h)$ & 2.5 & 7.1 & 3.8 & 2 & - & - & - \\
\hline FO\&M Cost $(\$ / \mathrm{kW} /$ Year) & 20 & 62.5 & 45 & 55 & 24 & 46 & 75 \\
\hline Start-up Cost $(\$ / \mathrm{MW})$ & 17 & 50 & 50 & - & - & - & 15 \\
\hline
\end{tabular}

Table 2. Economic parameters for each type of generation plant (Brouwer et al., 2015; International Energy Agency, 2016a, 2016b)

Twenty-five transmission interconnections between the regions (Figure 1) have been modelled in this study, with data on the maximum flow (line's thermal limit) obtained from WAPP master plan study data (West African Power Pool, 2011). Comprehensive details on the interconnections can be found in Table 2 of the Appendix. The transmission lines have been simplified and modelled as transport models therefore their reactance and resistance have not been included in the model. The losses on each transmission line are assumed to be $3 \%$ per $500 \mathrm{~km}(\mathrm{ABB}, 2015)$ based on the HVDC transmission technology.

\subsection{Scenarios}

We investigate two scenarios in the year 2025; baseline and renewable scenario. Each scenario has different levels of solar energy integration and are described in the following subsections.

3.3.1. Baseline scenario. In this scenario we assume all existing and planned national and regional generation and interconnections infrastructures are fully operational. This scenario aims to propose a realistic operation of the 2025 West African interconnected electricity network. Table 3 shows the generation capacity for each country in this scenario. Electricity trading is based on the existing trading plan in the region which is bilateral contracts between neighbouring countries. During simulation, we assume electricity trading between countries is only restricted by the maximum flow capacities of interconnection lines.

\begin{tabular}{|l|l|l|l|l|l|l|l|}
\hline Country & $\begin{array}{l}\text { Gas } \\
(\mathrm{MW})\end{array}$ & $\begin{array}{l}\text { Diesel } \\
(\mathrm{MW})\end{array}$ & $\begin{array}{l}\text { Coal } \\
(\mathrm{MW})\end{array}$ & $\begin{array}{l}\text { Hydro } \\
(\mathrm{MW})\end{array}$ & $\begin{array}{l}\text { Solar PV } \\
(\mathrm{MW})\end{array}$ & $\begin{array}{l}\text { Wind } \\
(\mathrm{MW})\end{array}$ & $\begin{array}{l}\text { Biomass } \\
(\mathrm{MW})\end{array}$ \\
\hline Benin/Togo & 137 & 127 & 0 & 306 & 16 & 25 & 0 \\
\hline Burkina Faso & 0 & 433 & 0 & 32 & 53 & 0 & 0 \\
\hline Cote d Ivoire & 1028 & 0 & 0 & 1283 & 15 & 0 & 71 \\
\hline Gambia & 0 & 156 & 0 & 128 & 30 & 5 & 0 \\
\hline Ghana & 2015 & 325 & 0 & 1040 & 158 & 225 & 0 \\
\hline Guinea & 0 & 188 & 0 & 1508 & 0 & 0 & 0 \\
\hline Guinea Bissau & 0 & 43 & 0 & 20 & 0 & 0 & 0 \\
\hline Liberia & 0 & 121 & 0 & 64 & 0 & 0 & 0 \\
\hline Mali & 55 & 289 & 0 & 455 & 110 & 1 & 0 \\
\hline Niger & 30 & 164 & 232 & 130 & 0 & 0 & 0 \\
\hline
\end{tabular}




\begin{tabular}{|l|l|l|l|l|l|l|l|} 
Nigeria & 10637 & 0 & 1200 & 6295 & 136 & 11 & 0 \\
\hline Senegal & 52 & 650 & 875 & 194 & 62 & 225 & 15 \\
\hline Sierra Leone & 0 & 61.9 & 0 & 228 & 5 & 0 & 15 \\
\hline
\end{tabular}

Table 3. Generation capacities in baseline scenario

3.3.2. Renewable scenario. West African region has a high potential of solar energy for the installation of solar PV plants as indicated by the $10 \mathrm{~km} \times 10 \mathrm{~km}$ resolution of Global Horizontal Irradiance (GHI) data in Figure 3 (ECOWAS Observatory for Renewable Energy and Energy Efficiency, 2017). This scenario assumes a significant increase in solar PV plants in each region. The capacities of additional solar PV plants are based on the estimated technical potential for utility solar PV plants connected to the grid (Yushchenko, de Bono, Chatenoux, Kumar Patel, \& Ray, 2016). This technical potential was calculated based on GHI values, proximity to electricity grid, population, distance to urban areas and excluded protected areas in the region.

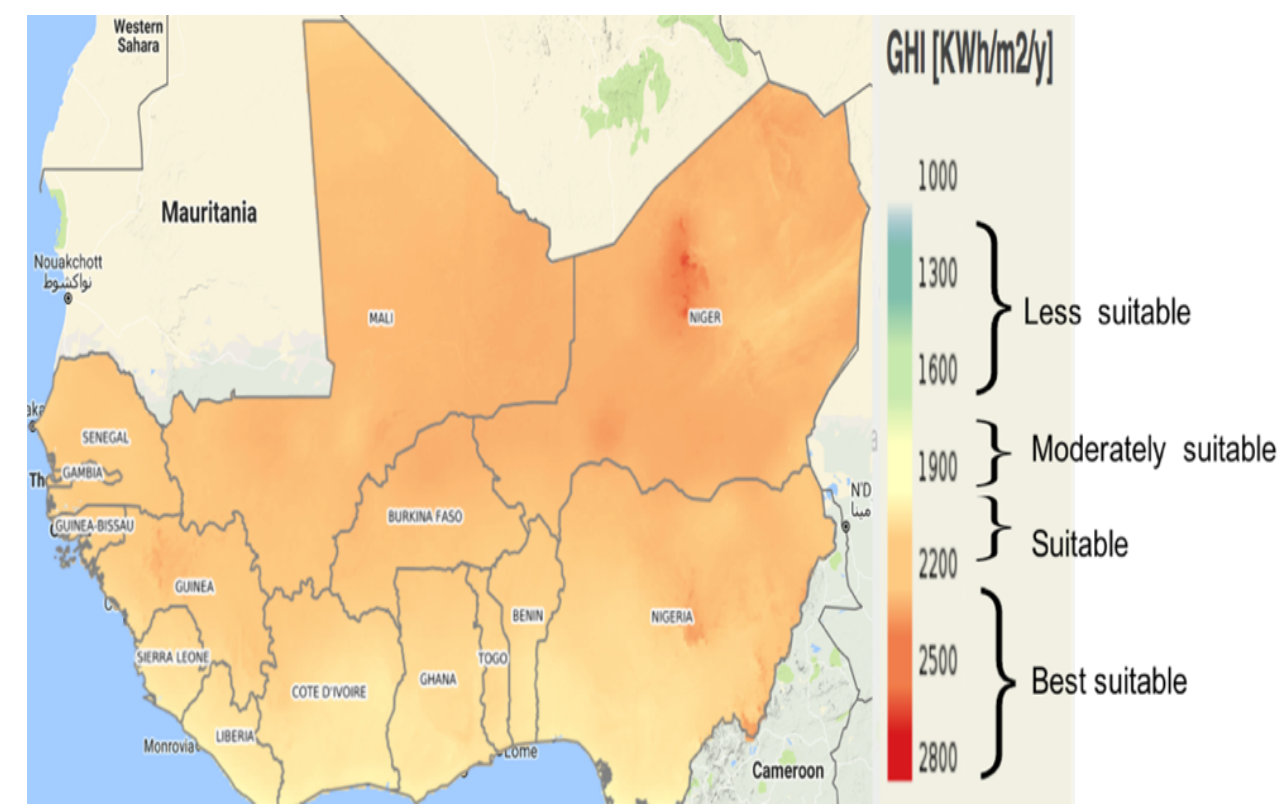

Figure 3. Global horizontal irradiance and suitability for Solar PV plants in West African Countries.

For this study, we assume $2 \%$ of the technical potential in each country is utilized and is evenly distributed amongst the different regions in the country. This method was employed to characterize the variability of solar PV generation in the different geographical locations in each country as portrayed by the hourly solar profiles from solar PV plants in the 3 regions of Côte d'Ivoire in Figure 4. In addition to installed generation capacities in the baseline scenario, an additional $71 \mathrm{GW}$ of solar PV plants is assumed to be installed and in operation across the different region. Table 3 in the Appendix shows additional grid connected solar PV plant for each region in this scenario. Electricity trading in the region is the same as the baseline scenario. This scenario aims to quantify the techno-economic impacts of high integration of solar PV plants in the interconnected network. 


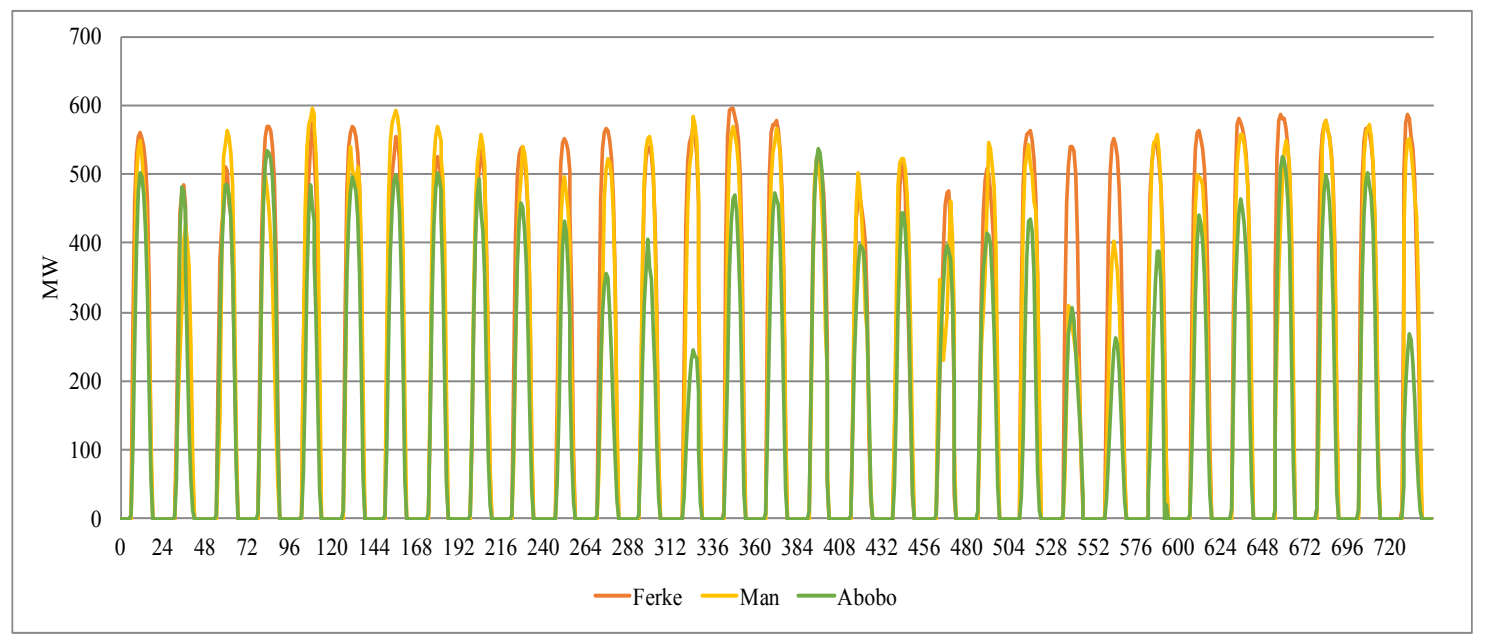

Figure 4. Hourly output from 758MW solar PV plants in 3 regions of Côte d'Ivoire in January 2014.

\section{Results}

To investigate the role and benefits of solar energy in meet rapidly growing demand in West Africa through an interconnected electricity network, we compare the baseline scenario of the 2025 power system with the renewable scenario of high integration of solar PV plants.

\subsection{Power systems operations}

In the baseline scenario, $55 \%$ of electricity generated is from gas plants, $9 \%$ from coal and $8 \%$ from diesel. Hydropower plants have a share of $27 \%$ in the generation mix and is the only renewable energy source with significant part in the mix. With an additional $71 \mathrm{GW}$ of solar PV plants in the renewable scenario, the share of gas and diesel plants reduce significantly to $37 \%$ and 3\% respectively. There is a $2 \%$ drop in hydropower generation while solar PV accounts for $28 \%$ in this scenario. Figure 5 shows the generation mix in each country in the baseline and renewable scenarios. The change in the generation mix can be attributed to the comparatively higher cost of imported fuel costs, O\&M costs, and start-up costs of gas and diesel plants in Benin/Togo, Burkina Faso, Gambia, Ghana, Guinea Bissau, Liberia, Mali and Senegal. The interconnected grid provided countries like Ghana, Liberia and Nigeria the opportunity to import electricity from least cost solar generation in Burkina Faso, Côte d'Ivoire, Guinea and Niger. 


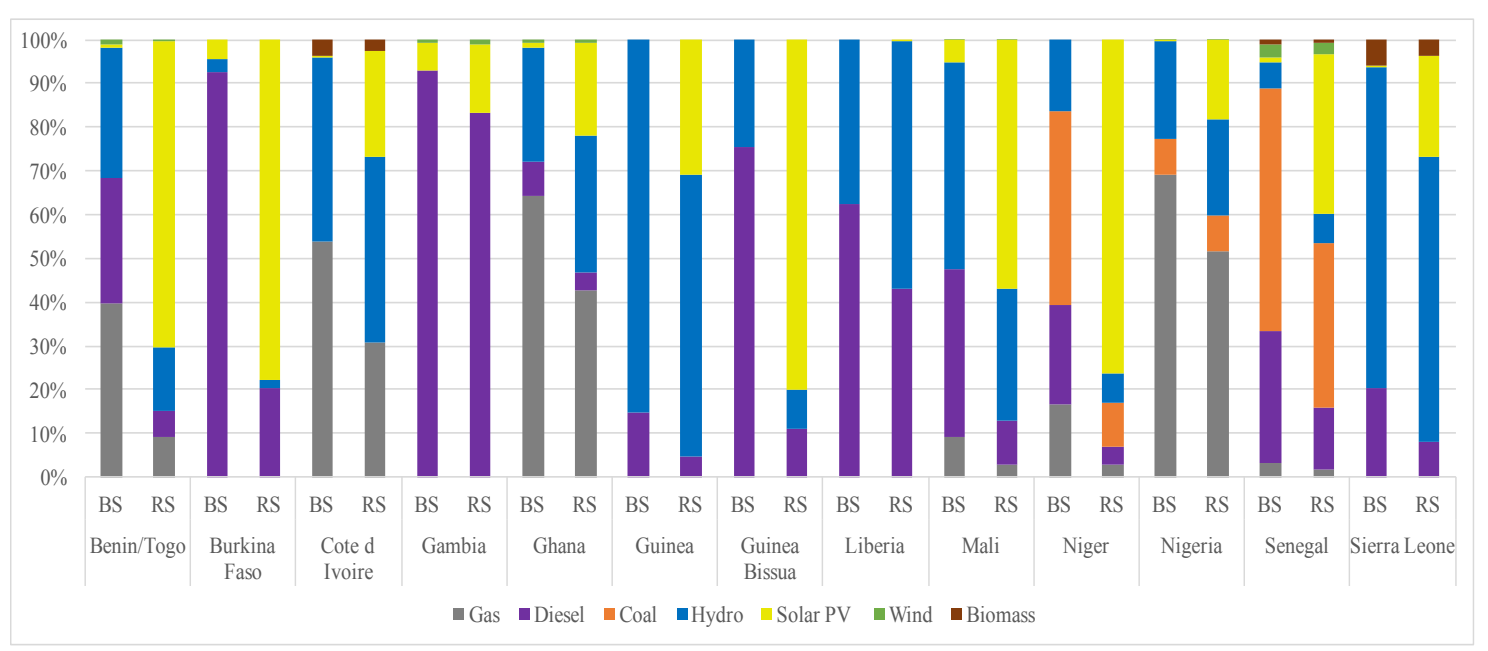

Figure 5. Electricity generation mix of West African countries in the Baseline (BS) and Renewable (RS) scenarios.

The change in the generation mix can be attributed to the comparatively higher cost of imported fuel costs, O\&M costs, and start-up costs of gas and diesel plants in Benin/Togo, Burkina Faso, Gambia, Ghana, Guinea Bissau, Liberia, Mali and Senegal. The interconnected grid provided countries like Ghana, Liberia and Nigeria the opportunity to import electricity from least cost solar generation in Burkina Faso, Côte d'Ivoire, Guinea and Niger. Despite the shift in the generation mix of the two scenarios, gas plants remain the dominant generation units supplying $100 \mathrm{TWh}$ and $71 \mathrm{TWh}$ in the two scenarios, as highlighted in Figure 6. While hydro power plants provide the baseload generation in both scenarios with 48.9TWh and 18.6TWh.

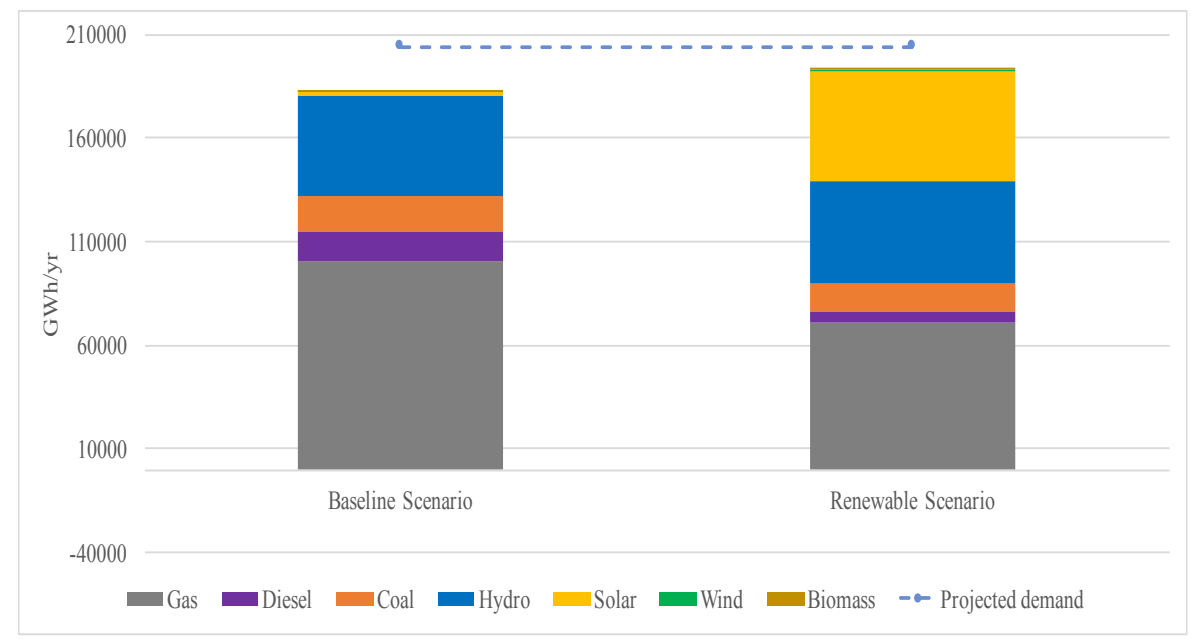

Figure 6. Annual regional electricity generation mix in the baseline and renewable scenarios.

The supply-demand gap in the baseline scenario is 10\% (Figure 6) which highlights the inadequacy of current and planned generation units in meeting the projected 2025 demand in the region. Comparing the baseline and renewable scenario, there is a 5\% decrease in the gap between supply and demand. Figure 7 shows the generation dispatch profiles of the baseline and renewable scenarios during the first week of March which is a dry season with 
comparatively higher demand. It can be seen that the daytime hourly economic dispatch in the renewable scenario shifts to the solar PV plants in the interconnected power system replacing generation from diesel plants and a significant portion of gas plants.
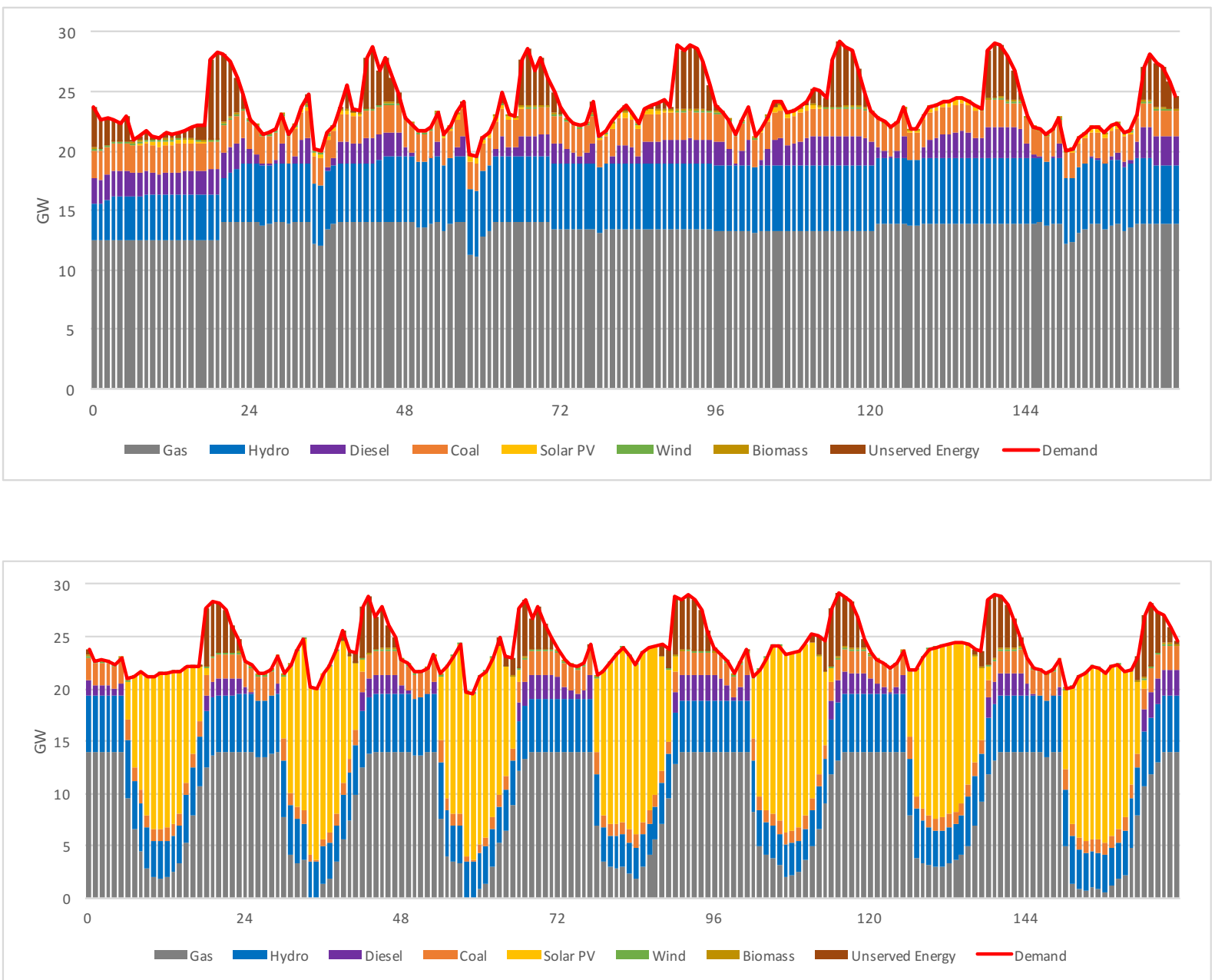

Figure 7. Weekly generation dispatch in the Baseline (top) and Renewable (Bottom) scenarios for the first week in March 2025.

Given the comparatively higher generation costs diesel plants, in the renewable scenario they are only switched on in the early morning and during the evening peak times when there is no generation from the solar PV plants. In both scenarios, there are unserved demand in the power system during the day when all available generation units are operating at their maximum capacities. However, unserved demand in the renewable scenario occurs only in the evening peak times. In the baseline scenario the annual unserved energy ranges from a minimum level of $3 \%$ in Senegal and Ghana to a maximum of $14 \%$ in Burkina Faso, Niger and Nigeria. In the renewable scenario, a minimum of $1 \%$ of annual unserved energy is experienced in 5 countries and a maximum of $7 \%$ in Nigeria which has the highest demand in the region. Niger experiences the highest reduction in unserved energy and can be attributed to the country having the maximum potential for solar PV plants in the region. Figure 7 also highlights the flexibility of thermal and hydro power plants in facilitating the integration of the intermittent solar PV supply. It is important to note that the flexibility data used in this study which includes minimum stable levels, ramp rate and start-up times, are based on assumptions in (International Energy Agency, 2014b) 


\subsection{Cross-border electricity trade}

Electricity trade between countries account for $35 \%$ of the total electricity generated in the region in both scenarios given that transmission infrastructures remain constant during simulation of the two scenarios. However, the major exporters and importers in both scenarios differ due to the high integration of solar PV plants in the interconnected network as shown in Figure 8. In the baseline scenario, the major exporters are Côte d'Ivoire, Niger, Nigeria and Senegal. Senegal is the largest exporter with 5TWh trading with Gambia, Guinea Bissau and Mail. In the renewable scenario, the major exporters now include Burkina Faso, Guinea, and Mali, while Nigeria and Ghana are now major importers. Coincidentally they are the two countries with the highest demand in the region and trade with neighbouring countries with comparatively lower demand and high integration of least cost solar PV plants. Niger is the largest exporter in the renewable scenario with 7.6TWh trading with Benin/Togo, Burkina Faso and Nigeria. The imported electricity from Niger accounts for $5 \%$ of the total annual electricity consumed in Nigeria.

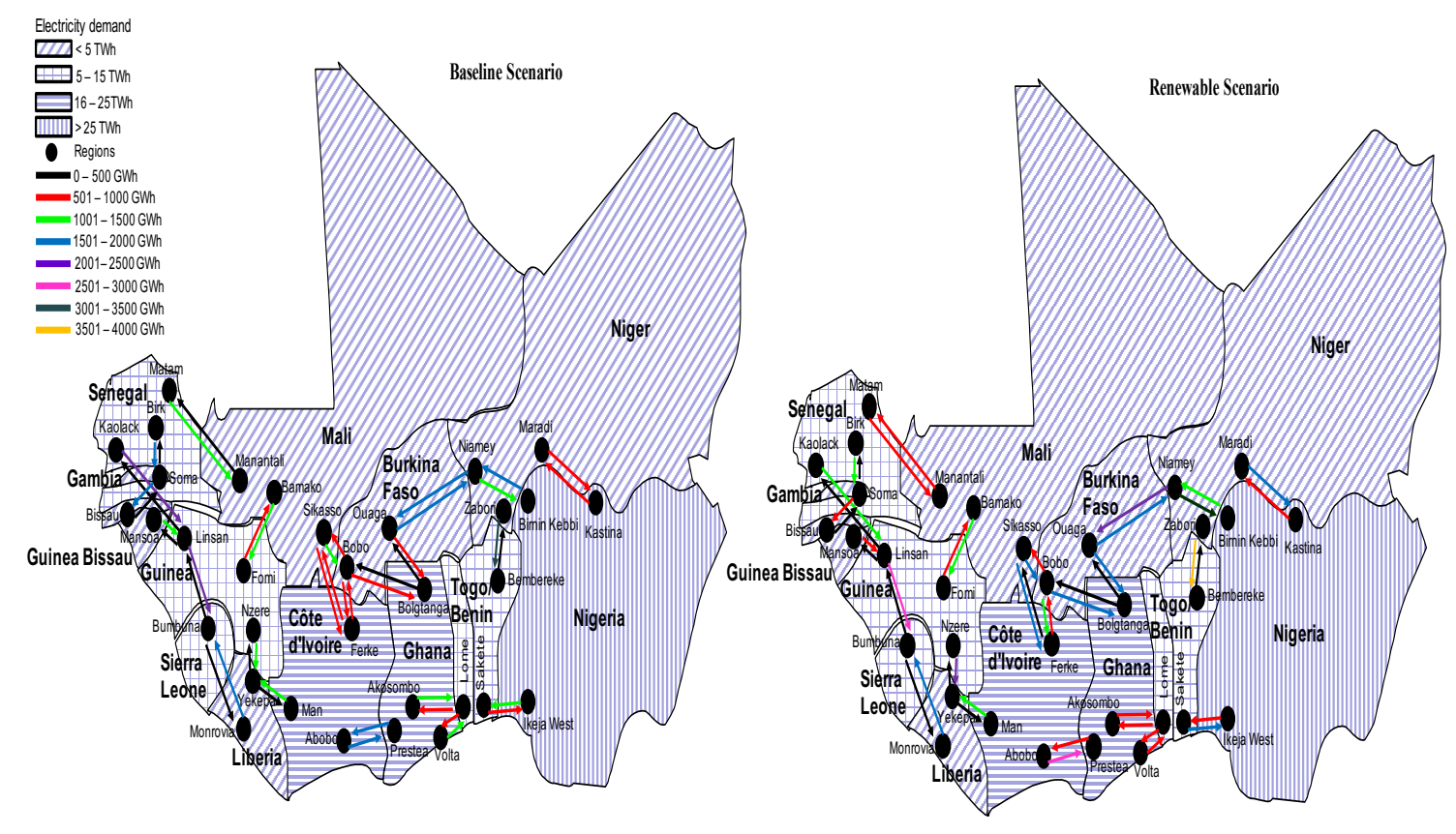

Figure 8. Cross-border electricity trade in the baseline and renewable scenarios.

Gambia and Ghana experience significant changes in terms of the amount of electricity imported in both baseline and renewable scenario, from $2 \%$ to $55 \%$ and $4 \%$ to $22 \%$ respectively. This is as a result of these two countries reducing generation from expensive diesel plants and relying on imports from solar PV plants. During electricity trading, Ghana and Liberia have the role of transfer countries. In the renewable scenario, Ghana imports 8.6TWh from Burkina Faso and Côte d'Ivoire and exports 3.2TWh to Benin/Togo, while Liberia imports 3.6TWh from Côte d'Ivoire and Guinea and exports 1.8TWh to Sierra Leone. These cross-border electricity trading results illustrate the role of the interconnected grid in increasing solar PV utilization with importing countries relying less on more expensive fossil power plants. 


\subsection{Power system costs}

Figure 9 shows the average generation cost in each country which includes fuel, variable O\&M and start-up costs. The figure illustrates results from the two scenarios that we analysed in this study and it can be seen that there are benefits in each country for the renewable scenario.

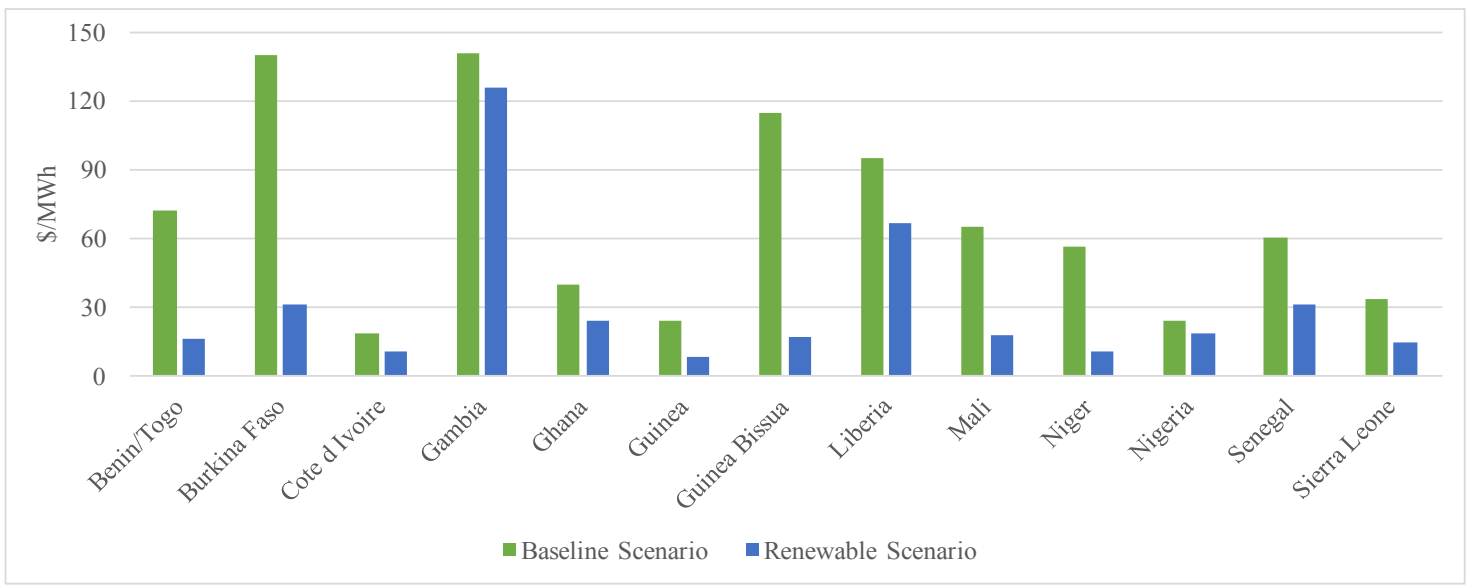

Figure 9. Average generation cost for each country in the baseline and renewable scenario.

Increase in solar PV plants results in an avoided generation cost in all countries with an average minimum value of $\$ 5 / \mathrm{MWh}$ in Nigeria to a maximum value of $\$ 109 / \mathrm{MWh}$ in Burkina Faso, their installed capacity in the baseline scenario are $34 \%$ hydro plants, $58 \%$ gas plants and $84 \%$ diesel plants and 6\% hydro plants respectively. In comparison to the baseline scenario, there is a total regional savings of up to $40 \%$ in annual generation cost in the renewable scenario as a result of solar PV generation replacing a significant portion of diesel and gas generation. This annual savings is higher than the estimated $20 \%$ in a previous study (Sparrow et al., 2002) due to the focus on solar PV plants in this study while the latter focused on hydro plants.

The short run marginal cost of generation which is the variable cost incurred in producing one more MW of electricity, is determined by heat rate, fuel prices and variable O\&M costs of generation units. Given the low marginal cost of solar PV plants there is an obvious decrease in the marginal cost of all countries in the renewable scenario. However, the countries that experience a significant decrease in its annual average marginal cost within a range of $55 \%$ to $57 \%$ are Burkina Faso, Gambia and Guinea Bissau. This is as a result of these countries having the highest share of diesel plants in its total installed capacities in the baseline scenario with $84 \%, 82 \%$ and $68 \%$ respectively.

\subsection{Sensitivity analysis}

We carried out sensitivity analysis on the renewable scenario to account for future uncertainty of demand growth and fossil fuel prices in the region. In the first analysis we assume a low projected demand scenario (West African Power Pool, 2011) which is based on slower rates of growth for GDP, population and electrification in each country. More details on maximum demand levels and energy consumption for each country is highlighted in Table 1 in the Appendix. The total projected energy consumption in this scenario is $17 \mathrm{TWh}$ which is $16 \%$ less than the renewable scenario. The results reveal that electricity generation from diesel, gas and biomass power plants reduce by $80 \%, 25 \%$, and $11 \%$ respectively in comparison to the renewable scenario. On the other hand, hydro power generation increases by just $3 \%$, while there is no significant impact on other technologies. The supply-demand gap in the low demand 
scenario has reduced to $3 \%$ with Nigeria being the only country with unserved energy of $6 \%$. We observe that electricity trading between countries is sensitive to a lower demand level, with most countries reducing import of electricity. However, Gambia, Liberia and Sierra Leone increase electricity imports by $15 \%, 13$ and $2 \%$ respectively, which reflects on the comparatively lower solar PV potentials in these countries. Decrease in demand levels results in total generation cost reducing by $37 \%$ for the entire region and higher cost savings for each country. A minimum avoided cost of $\$ 7 / \mathrm{MWh}$ was recorded in Nigeria and a maximum of \$131/MWh in Burkina Faso.

The second sensitivity analysis simulates the renewable scenario with four adjusted values of fossil fuel prices $(+10 \%,+20 \%,-10 \%,-20 \%)$. The results show that changes in fuel prices do not have significant impact on electricity generation from all technologies which also translates to no little or no impact on unserved energy and electricity trading in the region. This can be attributed to the inadequacy of regional generation capacity to meet demand and limited reserve units in few countries. The avoided average generation cost in each country were more sensitive to decreasing prices of fossil fuels than increasing prices.

\section{Conclusions}

In this study we investigate the impacts and benefits of high integration of solar energy on the interconnected electricity network in West Africa under the operation of a single regional market. We use a multi-region economic dispatch model with hourly simulations to analyse two scenarios with different levels of solar energy integration in the year 2025. Our results indicate that high integration of solar PV plants reduce the supply- demand gap in the region from $10 \%$ to $5 \%$. All countries except Nigeria have less than $1 \%$ of unserved demand in the year. We observe that the additional solar PV plants become economic replacements in countries that relied predominantly on diesel plants, with diesel plants only utilized when other available generation technologies are operating at maximum levels. With electricity trading based on generation from solar PV plants, regional generation from gas and diesel power plants is reduced by $18 \%$ and $5 \%$ respectively. As a result, all countries benefit from avoided generation cost with Burkina Faso having the highest avoided average cost savings of $\$ 109 / \mathrm{MWh}$. There are notable changes in the electricity import patterns in the region following the integration of the solar PV plants. For example, Gambia and Ghana increase their share of imports from $2 \%$ and $4 \%$ to $55 \%$ and $22 \%$ respectively.

The results show that increasing integration of solar energy in a fully interconnected West African electricity network significantly meets growing demand, reduces load shedding and generation costs. As a consequence, more countries rely on imports to meet more than $50 \%$ of its demand which could be a political challenge as governments may be against such a high level of external dependency of electricity supply. For the West African Power Pool keen on increasing electricity supply and reducing the current high electricity prices in the region, utilization of solar energy resources in combination with unexplored hydro resources provides an opportunity to achieve these goals. Results from our study may be applicable in planning the next phase of regional generation plants.

Future work will address the simplification of generation and transmission infrastructures in this study by further increasing the spatial resolution of our model. This will involve modelling individual centralized generation units and high voltage transmission grid in each country. Future work will also investigate storage technologies to compensate for the intermittent nature of solar PV plants and also replace diesel plants during peak periods. Further analysis will include an integrated single market with spot market operations. 


\section{Acknowledgments}

The authors will like to appreciate the WAPP Information and coordination Centre for the data they provided. The authors will like to thank the Petroleum Technology Development Fund Nigeria (PTDF) for funding this research. The views in this study are those of the authors and do not necessarily reflect the views of PTDF

\section{References}

ABB. (2015). Powering the world. Retrieved September 20, 2016, from https://library.e.abb.com/public/3e72a700e0eb4ba3c1257d380042702f/06-11

SR421_72dpi.pdf

Bogdanov, D., \& Breyer, C. (2016). North-East Asian Super Grid for 100\% renewable energy supply: Optimal mix of energy technologies for electricity, gas and heat supply options. Energy Conversion and Management, 112, 176-190. https://doi.org/10.1016/j.enconman.2016.01.019

Brancucci Martínez-Anido, C., Vandenbergh, M., de Vries, L., Alecu, C., Purvins, A., Fulli, G., \& Huld, T. (2013). Medium-term demand for European cross-border electricity transmission capacity. Energy Policy, 61, 207-222. https://doi.org/10.1016/j.enpol.2013.05.073

Brouwer, A. S., van den Broek, M., Seebregts, A., \& Faaij, A. (2015). Operational flexibility and economics of power plants in future low-carbon power systems. Applied Energy, 156, 107-128. https://doi.org/10.1016/j.apenergy.2015.06.065

Brouwer, A. S., van den Broek, M., Zappa, W., Turkenburg, W. C., \& Faaij, A. (2016). Leastcost options for integrating intermittent renewables in low-carbon power systems. Applied Energy, 161, 48-74. https://doi.org/10.1016/j.apenergy.2015.09.090

Castellano, A., Kendall, A., Nikomarov, M., \& Swemmer, T. (2015). Brighter Africa. Italy: McKinsey \& Company.

Cervigni, R., Liden, R., Neumann, J. E., \& Strzepek, K. M. (2015). Enhancing the Climate Resilience of Africa's Infrastructure. Enhancing the Climate Resilience of Africa's Infrastructure: The Power and Water Sectors. Washington DC: World Bank. https://doi.org/10.1596/978-1-4648-0466-3

Collins, S., Deane, J. P., \& Gallachóir, B. Ó. (2017). Adding value to EU energy policy analysis using a multi-model approach with an EU-28 electricity dispatch model. Energy, 130, 433-447.

Dominković, D. F., Bačeković, I., Ćosić, B., Krajačić, G., Pukšec, T., Duić, N., \& Markovska, N. (2016). Zero carbon energy system of South East Europe in 2050. Applied Energy, 184, 1517-1528. https://doi.org/10.1016/j.apenergy.2016.03.046

ECOWAS Observatory for Renewable Energy and Energy Efficiency. (2016). Power Plants. Retrieved September 4, 2016, from http://www.ecowrex.org/resources/energy_generators

ECOWAS Observatory for Renewable Energy and Energy Efficiency. (2017). Map Viewer. Retrieved January 12, 2017, from http://www.ecowrex.org/page/maps

Eser, P., Singh, A., Chokani, N., \& Abhari, R. S. (2016). Effect of increased renewables generation on operation of thermal power plants. Applied Energy, 164, 723-732. https://doi.org/10.1016/j.apenergy.2015.12.017

Fürsch, M., Hagspiel, S., Jägemann, C., Nagl, S., Lindenberger, D., \& Tröster, E. (2013). The role of grid extensions in a cost-efficient transformation of the European electricity system until 2050. Applied Energy, 104, 642-652. https://doi.org/10.1016/j.apenergy.2012.11.050

Gnansounou, E. (2008). Boosting the electricity sector in West Africa: An integrative vision. 
International Association for Energy Economics, 23-29.

Gnansounou, E., Bayem, H., Bednyagin, D., \& Dong, J. (2007). Strategies for regional integration of electricity supply in West Africa. Energy Policy, 35(8), 4142-4153. https://doi.org/10.1016/j.enpol.2007.02.023

Haller, M., Ludig, S., \& Bauer, N. (2012). Decarbonization scenarios for the EU and MENA power system: Considering spatial distribution and short term dynamics of renewable generation. Energy Policy, 47, 282-290. https://doi.org/10.1016/j.enpol.2012.04.069

Hermann, S., Miketa, A., \& Fichaux, N. (2014). Estimating the Renewable Energy Potential in Africa GIS-based approach. Abu Dhabi: International Renewable Energy Agency.

Huber, M., Roger, A., \& Hamacher, T. (2015). Optimizing long-term investments for a sustainable development of the ASEAN power system. Energy, 88, 180-193. https://doi.org/10.1016/j.energy.2015.04.065

International Energy Agency. (2014a). Africa Energy Outlook: A focus on energy prospects in Sub-Saharan Africa. France, France: International Energy Agency.

International Energy Agency. (2014b). The Power of Transformation: Wind, Sun and the Economics of Flexible Power Systems. France: International Energy Agency.

International Energy Agency. (2016a). Investment Costs. Retrieved December 7, 2016, from http://www.worldenergyoutlook.org/weomodel/investmentcosts/

International Energy Agency. (2016b). World Energy Outlook 2016. International Energy Agency. France: International Energy Agency.

International Energy Agency. (2017). Energy Technology Perspectives 2017. France: International Energy Agency. https://doi.org/10.1787/energy_tech-2017-en

Jacottet, A. (2012). Cross-border electricity interconnections for a well-functioning. Oxford Energy Comment.

Jaehnert, S., Wolfgang, O., Farahmand, H., Voller, S., \& Huertas-Hernando, D. (2013). Transmission expansion planning in Northern Europe in 2030-Methodology and analyses. Energy Policy, 61, 125-139. https://doi.org/10.1016/j.enpol.2013.06.020

Miketa, A., \& Merven, B. (2013). WEST AFRICAN POWER POOL: Planning and Prospects for Renewable Energy. Abu Dhabi: International Renewable Energy Agency (IRENA).

National Aeronautics and Space Administration. (2016). NASA Surface meteorology and Solar Energy - Location. Retrieved September 10, 2016, from https://eosweb.larc.nasa.gov/cgibin/sse/grid.cgi?email=skip@larc.nasa.gov

Otsuki, T., Mohd Isa, A. B., \& Samuelson, R. D. (2016). Electric power grid interconnections in Northeast Asia: A quantitative analysis of opportunities and challenges. Energy Policy, 89, 311-329. https://doi.org/10.1016/j.enpol.2015.11.021

Pfenninger, S., \& Staffell, I. (2016a). Long-term patterns of European PV output using 30 years of validated hourly reanalysis and satellite data. Energy, 114, 1251-1265. https://doi.org/10.1016/j.energy.2016.08.060

Pfenninger, S., \& Staffell, I. (2016b). Renewables.ninja. Retrieved July 12, 2016, from https://www.renewables.ninja

PLEXOS. (2016). PLEXOS Integrated Energy Model: Simulation software for energy market analysis. Retrieved February 21, 2016, from https://energyexemplar.com/software/plexosdesktop-edition/

Schaber, K., Steinke, F., \& Hamacher, T. (2012). Transmission grid extensions for the integration of variable renewable energies in Europe: Who benefits where? Energy Policy, 43, 123-135. https://doi.org/10.1016/j.enpol.2011.12.040

Schmid, E., \& Knopf, B. (2015). Quantifying the long-term economic benefits of European electricity system integration. Energy Policy, 87, 260-269. https://doi.org/10.1016/j.enpol.2015.09.026

Sparrow, F. T., Masters, W. A., \& Bowen, B. H. (2002). Electricity Trade and Capacity 
Expansion Options in West Africa Summary. United States: Purdue University.

Spataru, C., \& Barrett, M. (2012). The Smart Super-European Grid: Balancing Demand and Suppy. 2012 3rd IEEE PES Innovative Smart Grid Technologies Europe, 1-6. https://doi.org/10.1109/ISGTEurope.2012.6465852

Spiecker, S., Vogel, P., \& Weber, C. (2013). Evaluating interconnector investments in the north European electricity system considering fluctuating wind power penetration. Energy Economics, 37, 114-127. https://doi.org/10.1016/j.eneco.2013.01.012

United Nations Economic Commission for Africa. (2003). Assessment of Power Pooling Arrangements in Africa. United Nations.

Van Hulle, F., Tande, J. O., Uhlen, K., Warland, L., Korpås, M., Meibom, P., ... Larsen, H. (2009). Integrating Wind: Developing Europe's power market for the large-scale integration of wind power. Belgium: European Wind Energy Association.

WAPP- Information and Coordination Centre. (2016). Monthly Operations Report. Benin: West African Power Pool.

West African Power Pool. (1999). WAPP. Retrieved August 5, 2017, from http://www.ecowapp.org/en

West African Power Pool. (2011). Update of the ECOWAS Revised Master Plan for the Generation and Transmission of Electrical Energy: Final Report Volume 1: Study Data. Retrieved March 15, 2016, from http://www.ecowapp.org/sites/default/files/mp_wapp_volume_1.pdf

West African Power Pool. (2015). 2016 - 2019 WAPP Business Plan. Retrieved March 15, 2016, from http://www.ecowapp.org/sites/default/files/2015-2019_business_plan.pdf

World Bank. (2015). World Bank Open Data. Retrieved January 12, 2017, from http://data.worldbank.org

World Energy Council. (2003). The Potential for Regionally Integrated Energy Development in Africa: a Discussion Document. United Kingdom: World Energy Council.

World Energy Council. (2005). Regional Energy Integration in Africa. United Kingdom: World Energy Council.

Yushchenko, A., de Bono, A., Chatenoux, B., Kumar Patel, M., \& Ray, N. (2016). GIS-based assessment of photovoltaic (PV) and concentrated solar power (CSP) generation potential in West Africa. Renewable and Sustainable Energy Reviews, 81(February 2017), 20882103. https://doi.org/10.1016/j.rser.2017.06.021

Zickfeld, F., Wieland, A., Blohmke, J., Sohm, M., \& Yousef, A. (2012). Perspectives on a Sustainable Power System for EUMENA. Germany: Dii GmbH.

\section{Appendix}

\begin{tabular}{|l|l|l|l|l|}
\hline Country & $\begin{array}{l}\text { Energy } \\
\text { consumption for } \\
\text { Baseline and } \\
\text { Renewable energy } \\
\text { scenarios }(\mathrm{GWh})\end{array}$ & $\begin{array}{l}\text { Maximum } \\
\text { demand for } \\
\text { Baseline and } \\
\text { renewable energy } \\
\text { scenarios }(\mathrm{MW})\end{array}$ & $\begin{array}{l}\text { Energy } \\
\text { consumption } \\
\text { for low } \\
\text { growth } \\
(\mathrm{GWh})\end{array}$ & $\begin{array}{l}\text { Maximum } \\
\text { demand for } \\
\text { low growth } \\
\text { scenario } \\
(\mathrm{MW})\end{array}$ \\
\hline Benin/Togo & 7314 & 1193 & 5893 & 961 \\
\hline Burkina Faso & 2408 & 491 & 1959 & 399 \\
\hline Cote d Ivoire & 13284 & 2142 & 10369 & 1672 \\
\hline Gambia & 1017 & 163 & 806 & 129 \\
\hline Ghana & 24830 & 3675 & 18082 & 2682 \\
\hline
\end{tabular}




\begin{tabular}{|l|l|l|l|l|}
\hline Guinea & 7626 & 1164 & 7385 & 1122 \\
\hline Guinea Bissau & 1246 & 217 & 1159 & 195 \\
\hline Liberia & 2324 & 373 & 2227 & 354 \\
\hline Mali & 4282 & 693 & 3665 & 591 \\
\hline Niger & 2039 & 370 & 1725 & 280 \\
\hline Nigeria & 124393 & 20000 & 106415 & 17110 \\
\hline Senegal & 6983 & 1172 & 5806 & 975 \\
\hline Sierra Leone & 6413 & 967 & 6182 & 923 \\
\hline TOTAL & 204159 & 32620 & 171673 & 27393 \\
\hline
\end{tabular}

Table 1. Energy consumption and maximum demand levels for each country.

\begin{tabular}{|c|c|c|c|c|c|c|}
\hline Region 1 & Country & Region 2 & Country & $\begin{array}{l}\text { Maximum } \\
\text { Flow } \\
\text { Capacity } \\
\text { (MW) }\end{array}$ & $\begin{array}{l}\text { Voltage } \\
\text { Level } \\
(\mathrm{kV})\end{array}$ & $\begin{array}{l}\text { Length } \\
(\mathrm{km})\end{array}$ \\
\hline Abobo & $\begin{array}{l}\text { Cote d } \\
\text { Ivoire }\end{array}$ & Prestea & Ghana & 320 & 225 & 210 \\
\hline Abobo & $\begin{array}{l}\text { Cote d } \\
\text { Ivoire }\end{array}$ & Prestea & Ghana & 650 & 330 & 210 \\
\hline Akosombo & Ghana & Lome & Benin/Togo & 250 & 161 & 130 \\
\hline Bamako & Mali & Fomi & Guinea & 320 & 225 & 300 \\
\hline Bembereke & Benin/Togo & Zabori & Niger & 650 & 330 & 312 \\
\hline Birkelane & Senegal & Soma & Gambia & 340 & 225 & 90 \\
\hline Birnin Kebbi & Nigeria & Niamey & Niger & 200 & 132 & 255 \\
\hline Birnin Kebbi & Nigeria & Niamey & Niger & 650 & 330 & 255 \\
\hline Bissau & $\begin{array}{l}\text { Guinea } \\
\text { Bissua }\end{array}$ & Soma & Gambia & 330 & 225 & 180 \\
\hline Bobo-Dioulasso & $\begin{array}{l}\text { Burkina } \\
\text { Faso }\end{array}$ & Bolgatanga & Ghana & 330 & 225 & 380 \\
\hline Bobo-Dioulasso & $\begin{array}{l}\text { Burkina } \\
\text { Faso }\end{array}$ & Ferkessedougou & $\begin{array}{l}\text { Cote d } \\
\text { Ivoire }\end{array}$ & 320 & 225 & 205 \\
\hline Bobo-Dioulasso & $\begin{array}{l}\text { Burkina } \\
\text { Faso }\end{array}$ & Sikasso & Mali & 310 & 225 & 160 \\
\hline Bolgatanga & Ghana & Ouagadougou & $\begin{array}{l}\text { Burkina } \\
\text { Faso }\end{array}$ & 330 & 225 & 200 \\
\hline Bumbuna & $\begin{array}{l}\text { Sierra } \\
\text { Leone }\end{array}$ & Linsan & Guinea & 330 & 225 & 320 \\
\hline Bumbuna & $\begin{array}{l}\text { Sierra } \\
\text { Leone }\end{array}$ & Monrovia & Liberia & 300 & 225 & 330 \\
\hline Ferkessedougou & $\begin{array}{l}\text { Cote d } \\
\text { Ivoire }\end{array}$ & Sikasso & Mali & 320 & 225 & 210 \\
\hline
\end{tabular}




\begin{tabular}{|l|l|l|l|l|l|l|}
\hline Ikeja West & Nigeria & Sakete & Benin/Togo & 680 & 330 & 70 \\
\hline Kaolack & Senegal & Linsan & Guinea & 280 & 225 & 455 \\
\hline Kastina & Nigeria & Maradi & Niger & 200 & 132 & 140 \\
\hline Linsan & Guinea & Mansoa & $\begin{array}{l}\text { Guinea } \\
\text { Bissua }\end{array}$ & 310 & 225 & 300 \\
\hline Lome & Benin/Togo & Volta & Ghana & 655 & 330 & 100 \\
\hline Man & $\begin{array}{l}\text { Cote d } \\
\text { Ivoire }\end{array}$ & Yekepa & Liberia & 340 & 225 & 100 \\
\hline Manantali & Mali & Matam & Senegal & 250 & 225 & 450 \\
\hline Niamey & Niger & Ouagadougou & $\begin{array}{l}\text { Burkina } \\
\text { Faso }\end{array}$ & 640 & 330 & 420 \\
\hline Nzerekore & Guinea & Yekepa & Liberia & 340 & 225 & 40 \\
\hline
\end{tabular}

Table 2. Interconnection capacities 2025

\begin{tabular}{|l|l|l|}
\hline Region & Country & $\begin{array}{l}\text { 2\% of National Solar PV Grid } \\
\text { Connected Potential (MW) }\end{array}$ \\
\hline Abobo & Cote d Ivoire & 758 \\
\hline Akosombo & Ghana & 713 \\
\hline Bamako & Mali & 2058 \\
\hline Bembereke & Benin/Togo & 933 \\
\hline Birkelane & Senegal & 1855 \\
\hline Birnin Kebbi & Nigeria & 3629 \\
\hline Bissau & Guinea Bissua & 411 \\
\hline Bobo-Dioulasso & Burkina Faso & 5315 \\
\hline Bolgatanga & Ghana & 713 \\
\hline Bumbuna & Sierra Leone & 300 \\
\hline Ferkessedougou & Cote d Ivoire & 758 \\
\hline Fomi & Guinea & 1493 \\
\hline Ikeja West & Nigeria & 3629 \\
\hline Kaolack & Senegal & 1855 \\
\hline Kastina & Nigeria & 3629 \\
\hline Linsan & Guinea & 1493 \\
\hline Lome & Benin/Togo & 933 \\
\hline Man & Cote d Ivoire & 758 \\
\hline Manantali & Mali & 2058 \\
\hline Mansoa & Guinea Bissua & 411 \\
\hline Maradi & Niger & 8151 \\
\hline Matam & Senegal & 1855 \\
\hline Monrovia & Liberia & 0.5 \\
\hline Niamey & Niger & 8151 \\
\hline Nzerekore & Guinea & 1493 \\
\hline Ouagadougou & Burkina Faso & 5315 \\
\hline Prestea & Ghana & 713 \\
\hline Sakete & Benin/Togo & 933 \\
\hline & &
\end{tabular}




\begin{tabular}{|l|l|l|}
\hline Sikasso & Mali & 2058 \\
\hline Soma & Gambia & 21 \\
\hline Volta & Ghana & 713 \\
\hline Yekepa & Liberia & 0.5 \\
\hline Zabori & Niger & 8151 \\
\hline
\end{tabular}

Table 3. Grid connected Solar PV Potential for each region 